\section{Investigation of chemical constituents of Artemisia albicerata}

${ }^{1}$ Amantay A., ${ }^{1}$ Kudaibergen A. ${ }^{1}$ Dyusebaeva M., ${ }^{2}$ Feng Y., ${ }^{1,3,4}$ Jenis J.*

${ }^{1}$ Faculty of Chemistry and Chemical Technology, al-Farabi Kazakh Nationa University, Almaty, Kazakhstan ${ }^{2}$ Shanghai Institute of Materia Medica Chinese Academy of Science, Shanghai, Chin ${ }^{3}$ Research Center for Medicinal Plants, al-Farabi Kazakh National University, Almaty, Kazakhstan

${ }^{4}$ Griffith Institute for Drug Discovery Brisbane, Australia

*E-mail: janarjenis@mail.ru
Artemisia albicerata is of great interest and occupy an important place among the vast variety of medicinal plants in Kazakhstan due to its endemicity, medical and pharmacological properties, and has a rich chemical composition consisting of amino acids, fatty acids, macro-micro elements, flavonoids and other low-molecular substances. In the present study, Artemisia albicerata, collected in Almaty region of Kazakhstan has been explored with the purpose of quantitative and qualitative analysis. As a result, twenty amino and eight fatty acids were identified by gas-liquid chromatography. The major amino acid contents were glutamate $(2615 \mathrm{mg} / 100 \mathrm{~g})$, aspartate $(1296 \mathrm{mg} / 100 \mathrm{~g})$ and alanine $(890 \mathrm{mg} / 100 \mathrm{~g})$, while the composition of fatty acids mainly was oleic $(19.6 \%)$ and linoleic $(68.4 \%)$ acids. Furthermore, eleven macro-micro elements were determined in the ash of a plant by the method of multi-element atomic emission spectral analysis, main of them were Ca $(60.0 \mathrm{mg} / \mathrm{g}), \mathrm{K}(60.4 \mathrm{mg} / \mathrm{g}), \mathrm{Mg}(12.2 \mathrm{mg} / \mathrm{g}), \mathrm{Na}(5.57 \mathrm{mg} / \mathrm{g}), \mathrm{Fe}(3.57 \mathrm{mg} / \mathrm{g})$. Also it should be highlighted that total bioactive components such as organic acids, flavonoids, tannins, coumarins, alkaloids, saponins, polysaccharides together with the moisture content $(6.62 \%)$, total ash $(7.96 \%)$ and extractives $(12.7 \%)$ have been determined.

Keywords: Artemisia albicerata; bioactive components; macro-, microelements; aminoacids; fatty acids.
Artemisia albicerata-ның химиялық құрамын зерттеу

${ }^{1}$ Амантай Ә., ${ }^{1}$ Құдайберген А. ${ }^{1}$ Дюсебаева М., ${ }^{2}$ Фенг Я., ${ }^{1,3,4}$ Жеңіс Ж.*

${ }^{1}$ Химия және химиялық технология факультеті, Әл-Фараби атындағы Қазақ ұлттық университеті, Алматы, Казақстан ${ }^{2}$ Шанхай дәрілік препараттар институты, Қытай ғылым академиясы Шанхай, Қытай

${ }^{3}$ Дәрілік өсімдіктерді ғылыми зерттеу орталығы, Әл-Фараби атындағы Қазақ ұлттық университеті, Алматы, Казақстан

${ }^{4}$ Дәрілік заттарды зерттеу Гриффит институты, Брисбен, Австралия *E-mail: janarjenis@mail.ru
Қазіргі таңда, Artemisia albicerata өзінің эндемиялық, медициналық және фармакологиялық қасиеттеріне байланысты Қазақстандағы көптеген дәрілік өсімдіктердің арасында маңызды орын алады. Сонымен бірге, амин және май қышқылдарынан, макро-микро элементтерден, флавоноидтерден, тағы да басқа төмен молекулалық заттардан тұратын бай химиялық құрамға ие болғандықтан, үлкен қызығушылық тудырады. Бұл жұмыста Алматы облысында жиналған Artemisia albicerata алғаш рет сандық және сапалы талдауы мақсатында зерттелді. Нәтижесінде, газды сұйықтықты хроматографияны қолдана отырып, жиырма амин және сегіз май қышқылдары анықталды. Амин қышқылдардың негізгі құрамы глутамат (2615 мг/100 г), аспартат (1296 мг/100 г) және аланин (890 мг/100 г); май қышқылдырдың - олеин $(19,6 \%)$ және линол $(68,4 \%)$ қышқылдары болып табылды. Сонымен қатар, атомдық эмиссия спектральды талдау әдісі арқылы он бір макро- және микроэлементтер зерттелді. Оның ішінде негізгі құрамь - Ca $(60,0 \mathrm{Mr} / \Gamma), \mathrm{K}(60,3 \mathrm{Mr} / \mathrm{r}), \mathrm{Mg}(12,2 \mathrm{Mr} / \mathrm{r})$, Na $(5,57 \mathrm{Mr} / \Gamma)$, Fe (3,57 мг/r). Бұдан басқа, Artemisia albicerata-ның құрамынан органикалык қышқылдар, флавоноидтар, таниндер кумариндер, алкалоидтар, сапониндер, полисахаридтер сияқты биологиялық активті компоненттермен бірге Өсімдіктің ылғалдылығы (6,62\%), күлділігі $(7,96 \%)$ және экстрактивтілігі $(12,7 \%)$ айқындалды.

Түйін сөздер:Artemisia albicerata;биоактивтікомпоненттер;макро-, микроэлементтер; амин қышқылдар; май қышқылдар.

\section{Исследование химического состава Artemisia albicerata}

${ }^{1}$ Амантай Ә., ${ }^{1}$ Кудайберген А., ${ }^{1}$ Дюсебаева М., ${ }^{2}$ Фенг Я., 1,3,4Женис Ж.*

${ }^{1}$ Факультет химии и химической технологии, Казахский национальный университет имени аль-Фараби, Алматы, Казахстан ${ }^{2}$ Шанхайский институт лекарственных препаратов, Китайская академия наук Шанхай, Китай

${ }^{3}$ Научно-исследовательский центр лекарственных растений, Казахский национальный университет имени аль-Фараби, Алматы, Казахстан

${ }^{4}$ Институт Гриффита по исследованию лекарств, Брисбен, Австралия *E-mail: janarjenis@mail.ru
Artemisia albicerata занимает важное место среди огромного разнообразия лекарственных растений в Казахстане и представляет большой интерес благодаря своей эндемичности, медицинским и фармакологическим свойствам, также в связи с богатым химическим составом, состоящий из аминокислот, жирных кислот, макро-микроэлементов, флавоноидов и других низкомолекулярных веществ. В данной работе, Artemisia albicerata, собранная в Алматинской области была впервые исследована с целью количественного и качественного анализов. В результате использования газо-жидкостной хроматографии, в составе Artemisia albicerata были идентифицированы двадцать амино- и восемь жирных кислот. Основное содержание аминокислот составляют глутамат (2615 мг/100 г), аспартат (1296 мг/100 г) и аланин (890 мг/100 г); жирных кислот-олеиновая $(19,6 \%)$ илинолевая $(68,4 \%)$ кислоты. Кроме того, методом многоэлементного спектрального анализа атомной эмиссии в золе растения были определены одиннадцать макро-, микроэлементов, основными из которых являются Сa (60,0 мг/г), K (60,3 мг/г), Mg (12,2 мг/г), Na (5,57 мr/г), Fe (3,57 мг/г). Также были диагностированы биологически активные компоненты, как органические кислоты, флавоноиды, дубильные вещества, кумарины, алкалоиды, сапонины, полисахариды вместе с содержанием влаги (6,62\%), общей золы $(7,96 \%)$ и экстрактивных веществ $(12,7 \%)$.

Ключевые слова: Artemisia albicerata; биоактивные компоненты; макро-, микроэлементы; аминокислоты; жирные кислоты. 


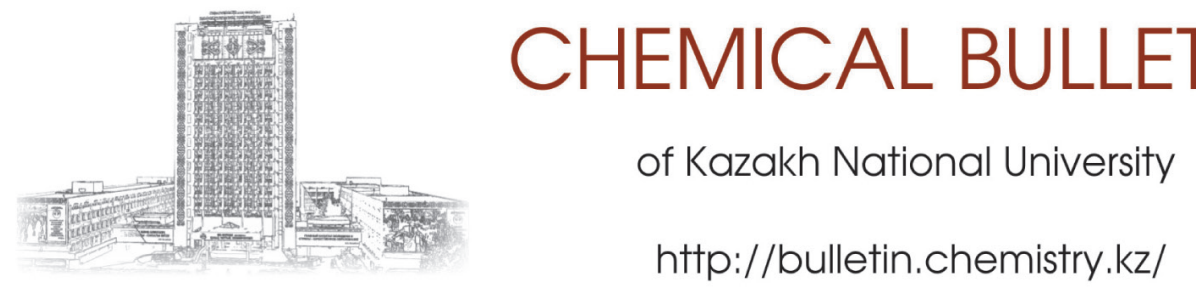

https://doi.org/10.15328/cb1055

\title{
Investigation of chemical constituents of Artemisia albicerata
}

\author{
${ }^{1}$ Amantay A., ${ }^{1}$ Kudaibergen A., ${ }^{1}$ Dyusebaeva M., ${ }^{2}$ Feng Y., ${ }^{1,3,4}$ Jenis J.* \\ ${ }^{1}$ Faculty of Chemistry and Chemical Technology, al-Farabi Kazakh National University, Almaty, Kazakhstan \\ ${ }^{2}$ Shanghai Institute of Materia Medica, Chinese Academy of Science, Shanghai, China \\ ${ }^{3}$ Research Center for Medicinal Plants, al-Farabi Kazakh National University, Almaty, Kazakhstan \\ ${ }^{4}$ Griffith Institute for Drug Discovery, Brisbane, Australia \\ *E-mail: janarjenis@mail.ru
}

\section{Introduction}

Artemisia albicerata is a herbaceous plant of the genus Artemisia and an endemic plant of Kazakhstan [1], which is promising as a source of a great amount of flavonoids, as well as individual flavonoids (rutin, quercetin-3-glucogalactoside) that stimulate or inhibit a particular enzymatic process. Therefore, studying such substances is crucial for medicine and agriculture [2]. Artemisia species are usually silver green or dark green, have pungent smell and bitter taste due to the presence of terpenoids and sesquiterpene lactones [3]. Meticulous phytochemical and pharmacological studies on Artemisia species demonstrated that many of them are responsible for various biological activities such as antimicrobial, antioxidant [4] and antimalarial [5]. Aerial parts and leaves are used to treat a wide range of diseases including gastric trouble, liver dysfunction and skin inflammation [6].

Artemisia albicerata is a largely unexplored plant that has been mentioned in several articles related to the determination of its phenolic composition $[2,7]$. Consequently, in the present survey, for the first time, there was a study that verifies quantitative, qualitative analysis, macro-, micro elements and amino-, fatty acids of Artemisia albicerata which grown in Almaty region of Kazakhstan, also, due to the fact that above substances are effective in the fight against diabetes, metabolic disorders and have a rejuvenating effect $[8,9]$. Furthermore, in contemporary times, it is a well-known fact that obesity is becoming a thorny problem. Amino acids improve not only indicators of health, but also facitate the loss of weight. Especially, arginine, cysteine and phenylalanine. Resolvins in fatty acids contribute to the growth of nerve cells and health in the treatment of diabetic neuropathy, which is one of the most dangerous complications of diabetes.

\section{Experiment}

\subsection{Plant material}

Artemisia albicerata was collected and rigorously studied by Dr. Alibek Ydyrys, The Herbarium of Laboratory Plant Biomorphology, Faculty of Biology and Biotechnology, Al-Farabi Kazakh National University in Almaty region, Kazakhstan at the end of August in 2018. Subsequently, it was dried at a room temperature in a well-ventilated room in presence of sunlight, then cut into small pieces.

\subsection{The quantitative and qualitative analysis}

The quantitative and qualitative analysis of bioactive constituents of Artemisia albicerata were explored according to methods reported in the monograph [10]. The content of extractives in Artemisia albicerata has been determined by $70 \%, 80 \%$ ethanol solutions in water in accordance with method reported in the State Pharmacopeia X [11].

\subsection{The determination of fatty acids}

The content of fatty acids was identified on a gas chromatograph Carlo-Erba-4200 (Italy) using the following chromatographic conditions are following: carrier gas used is 4.6 grade helium supplied at the rate of $30 \mathrm{~mL} / \mathrm{min}$, flame ionization detector temperature of $188^{\circ} \mathrm{C}$, oven temperature of $230^{\circ} \mathrm{C}$; analysis time of $1 \mathrm{~h}$, steel column of a size $0.4 \mathrm{~m} \times 3 \mathrm{~mm}$ filled with polyethylene glycol adipate (20\%) on cellite-545 (China).

Sample preparation stage: $10.0 \mathrm{~mL}$ of methanol $(90 \%$, Russia), 2-3 drops of acetyl chloride ( $40 \%$ solution, China) were added to chloroform extracts of the studied samples and then methylation was carried out at $60-70^{\circ} \mathrm{C}$ for $30 \mathrm{~min}$. Methanol was removed using a rotary evaporator, and samples were extracted with $5.0 \mathrm{~mL}$ of hexane and analyzed on a gas chromatograph [12]. The determination was made in the Kazakh Academy of Nutrition. 


\subsection{The determination of amino acids}

Conditions for the quantitative analysis of amino acids: the temperature of flame ionization detector $300^{\circ} \mathrm{C}$, carrier gas 4.6 grade helium, inlet temperature $250^{\circ} \mathrm{C}$ and chromosorb WA-W120-140 mesh as a stationary phase. Aqueous extraction of samples was hydrolyzed using 5 volumes of $\mathrm{HCl}(10 \%$ solution, Kazakhstan) within a period of $24 \mathrm{~h}$. Then, the hydrolyzate was evaporated in a rotary machine IKA RV 10 (Germany) at $40^{\circ} \mathrm{C}$ and after the centrifugation at a speed of 2,500 rpm, the precipitation is dissolved in 2 volumes of sulfosalicylic acid (60\%, Russia). Subsequently, the extracts were eluted through the ion exchange column with Dowex-50. After that, to the eluates, freshly prepared one drop of 2,2-dimethoxypropane (98\%, Kazakhstan) and one volume of propanol (60\%, Russia), saturated with $1 \mathrm{~N}$ hydrochloric acid were added. The next step involved appending acylating reagent (1 volume of acetic anhydride (Russia), 2 volumes of triethylamine (Russia), 5 volumes of acetone (Russia)) to the flask through vapour with a subsequent addition of $2.0 \mathrm{~mL}$ of ethyl acetate (Russia) and saturated 1 volume of $\mathrm{NaCl}$ solution (Kazakhstan). Finally, the ethyl acetate layer was evaluated on gas chromatograph [13]. The determination was made in the Kazakh Academy of Nutrition.

\subsection{The determination of macro-, microelements}

The mineral composition was identified, utilizing a Shimadzu 6200 series spectrometer. $2.52 \mathrm{~g}$ of raw material was placed in a pre-calcined and accurately weighted porcelain crucible. Then the crucible was gently heated, first letting the substance burn at the lowest possible temperature, and the flame was gradually increased. Calcination was performed at $500^{\circ} \mathrm{C}$ to obtain a constant mass. At the end of the calcination, the crucible was cooled in a desiccator and then the resulting ash was burned again at $600^{\circ} \mathrm{C}$ until a uniform gray color was obtained. The ash of Artemisia albicerata (0.199 g) was dissolved in $10.0 \mathrm{~mL}$ of $40 \%$ nitric acid by heating. After that, the resulting solution was heated to obtain wet salts. Subsequently, it was dissolved in $15.0 \mathrm{~mL}$ of $1 \mathrm{~N}$ nitric acid and transferred to a $25.0 \mathrm{~mL}$ volumetric flask for analysis.

\section{Results and Discussion}

\subsection{The quantitative and qualitative analysis}

Quantitative and qualitative analysis of bioactive constituents, moisture content, total ash and extractives were determined in Artemisia albicerata. The results are illustrated in Table 1.

Moisture and ash content vary within certain limits for every plant and depends on the nature of the plant material itself, how it is collected and dried. For Artemisia albicerata the limit is $13 \%$, according to the State Pharmacopeia X [11] Therefore, the determination of these contents was necessary to prove the good quality of Artemisia albicerata.

The largest quantity of extractives in Artemisia albicerata was obtained with $70 \%$ alcohol. Thus, this appropriate solvent could be utilized in the extraction. The identification of extractive substances by an appropriate solvent is important as it determines the good quality of plant for the content of biological metabolites.

During the quantitative analysis, it became clear that the contents of alkaloids, saponins and flavonoids are higher than that of other biologically active substances. Accordingly, it is logical to conclude that Artemisia albicerata could be potential source of above, significant constituents. Investigation of these bioactive constituents is crucial for medicine because flavonoids are now considered as an indispensable component in a variety of nutraceutical, pharmaceutical, medicinal and cosmetic applications. This is attributed to their anti-oxidative, anti-inflammatory, anti-mutagenic and anti-carcinogenic properties coupled with their capacity to modulate key cellular enzyme function [14]. As regards alkaloids, they are important secondary metabolites that are known to possess therapeutic properties. Moreover able to prevent the onset of various degenerative diseases by free radical scavenging or binding with the oxidative reaction catalyst [15]. Additionally, saponins influence plasma cholesterol levels positively and obtain anticarcinogenic, antioxidant activities, inhibitory effect on infectivity of HIV in vitro, in addition, protective effect on liver injury. Prevent hypercholesterolemia and aortic atherosclerosis.

Table 1 - Quantitative analysis of biologically active constituents of Artemisa albicerata

\begin{tabular}{cc}
\hline Component & Content, \% \\
\hline Moisture & 6.62 \\
Ash & 7.96 \\
Extractives & 12.71 \\
Alkaloids & 8.30 \\
Saponins & 7.76 \\
Flavonoids & 7.26 \\
Polysaccharides & 1.44 \\
Tannins & 1.33 \\
Coumarins & 0.33 \\
Organic acids & 0.32 \\
\hline
\end{tabular}

\subsection{Fatty acids analysis}

Regarding fatty acids, primarily there were oleic (19.6\%) and linoleic (68.4\%) acids (Figure 1). Artemisia albicerata is definitely one of the precious sources of linoleic acid, which is substantial for skin health. Also, it is vital as a precursor of the LCPUFAs that are incorporated into cell membranes in the form of phospholipids and other lipid components [16]. This acid increases the level of arachidonic acid, which is the main precursor of a series of bioactive metabolites called eicosanoids, which regulate a large number of physiological processes [17]. 


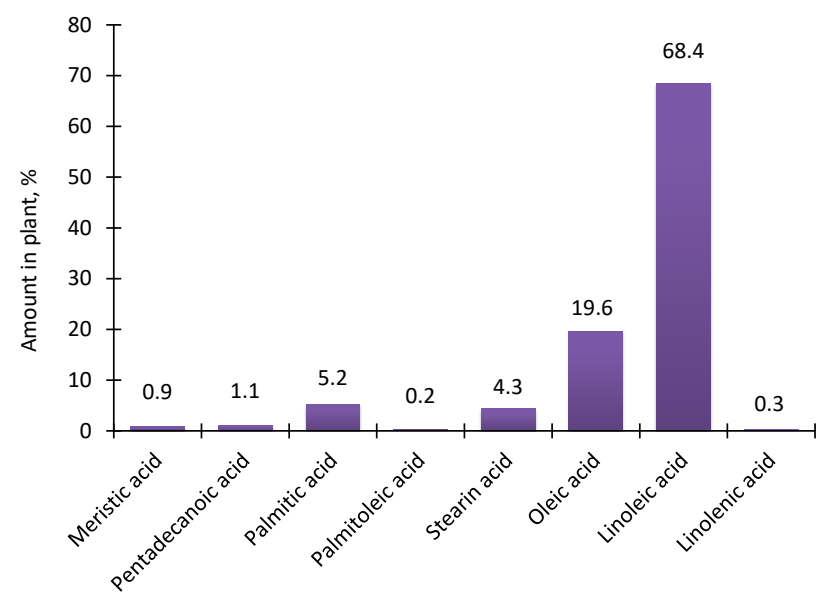

Figure 1 - Fatty acid contents of Artemisia albicerata

\subsection{Amino acids analysis}

Artemisia albicerata contains glutamate $(2615 \mathrm{mg} / 100 \mathrm{~g})$, aspartate $(1300 \mathrm{mg} / 100 \mathrm{~g})$ and alanine $(890 \mathrm{mg} / 100 \mathrm{~g})$ as shown in Figure 2. Furthermore, based on the results, it is sensible to assume that Artemisia albicerata contains almost all essential amino acids such as valine, isoleucine, leucine, lysine, methionine, threonine, tryptophan and phenylalanine and can be used to obtain them.

\subsection{Macro-, microelements}

Eleven macro-, micro elements were obtained from the ash of plant. Main of them were Ca $(60.0 \mathrm{mg} / \mathrm{g}), \mathrm{K}(60.4 \mathrm{mg} / \mathrm{g})$,
$\mathrm{Mg}(12.2 \mathrm{mg} / \mathrm{g}), \mathrm{Na}(5.57 \mathrm{mg} / \mathrm{g})$, Fe $(3.57 \mathrm{mg} / \mathrm{g})$ as shown in Table 2. It appears that Artemisia albicerata is a great source of macro- and micro elements, which are necessary for the functioning of the muscular, cardiovascular, immune, nervous systems and participate in the synthesis of vital compounds, metabolic processes, blood formation, digestion and neutralization of metabolic products.

Table 2 - Composition of macro-micro elements in the sample of Artemisia albicerata

\begin{tabular}{ccc}
\hline Element & $\begin{array}{c}\text { Concentration in ash, } \\
\mathrm{mg} / \mathrm{g}\end{array}$ & $\begin{array}{c}\text { Concentration in plant, } \\
\mathrm{mg} / \mathrm{g}\end{array}$ \\
\hline $\mathrm{Ca}$ & 60.0 & 4.73 \\
$\mathrm{~K}$ & 60.4 & 4.76 \\
$\mathrm{Mg}$ & 12.2 & 0.960 \\
$\mathrm{Na}$ & 5.57 & 0.439 \\
$\mathrm{Fe}$ & 3.57 & 0.282 \\
$\mathrm{Mn}$ & 0.321 & 0.0253 \\
$\mathrm{Zn}$ & 0.182 & 0.0144 \\
$\mathrm{Cu}$ & 0.0589 & 0.00470 \\
$\mathrm{Ni}$ & 0.0382 & 0.00300 \\
$\mathrm{~Pb}$ & 0.0114 & 0.000900 \\
$\mathrm{Cd}$ & 0.00120 & 0.000100 \\
\hline
\end{tabular}

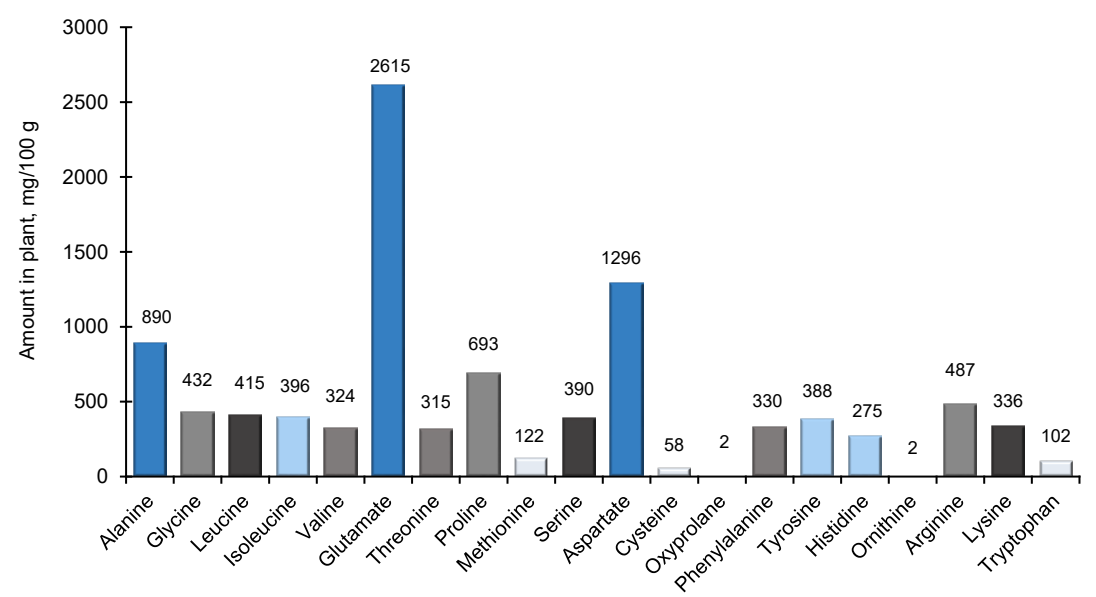

Figure 2 - Amino acid contents of Artemisia albicerata

\section{Conclusions}

To sum up, the investigation of phytochemical constituents of endemic plant Artemisia albicerata grown in Almaty region of Kazakhstan has been made for the first time. This research demonstrated total biologically active components, twenty amino and eight fatty acids, eleven macro-micro elements of Artemisia albicerata, as well as constituent importance of these substances. According to the results of the present study, it has been proven that this plant is one of the valuable sources of alkaloids, saponins, flavonoids, moreover, linoleic acid, aspartate, glutamate and alanine, furthermore, macro-micro 
elements, such as $\mathrm{Ca}, \mathrm{K}, \mathrm{Mg}, \mathrm{Na}$ and Fe. Thus, it is logical to conclude that presence of these bioactive constituents in Artemisia albicerata may indicate that the plant contains substances capable to prevent cardio vascular diseases, stroke and breast cancer, also, to promote a better brain activity, transamination reactions, the production of immunoglobulin and antibody synthesis, to enhance immune system and provide energy for brain, central nervous system and the muscle tissues.
That's why, the results indicated in the article prove the necessity to a further thorough study.

\section{Acknowledgements}

The work was supported by grants from Ministry of Education and Science of the Republic of Kazakhstan (IRN: AP05133199).

\section{References (GOST)}

1 Pavlov N.V. Flora of Kazakhstan [Flora Kazakhstana]. - Alma-Ata: Academy of Sciences of the Kazakh SSR, 1966. (In Russian) 2 Alukina L.S., Ryakhovskaya T.V. The flavonoids of the genus Artemisia of the subgenus Dracunculus of the flora of Kazakhstan [Flavonoidy roda Artemisia podroda Dracunculus flory Kazakhstana] // Academy of Sciences of the Kazakh SSR: Plant resources [AN KazSSR: Rastitel'nyye resursy]. 1980. - №16(2). - P.187-192. (In Russian)

3 Abad M.J., Bedoya L.M., Apaza L., Bermejo P. The Artemisia genus: a review of bioactive essential oils // Molecules. - 2012. Vol.17. - P.2542-2566.

4 Altunkaya A., Yildirim B., Ekici K., Terzioglu O. Determining essential oil composition, antibacterial and antioxidant activity of water wormwood extracts // GIDA. - 2014. - Vol. 39, Is.1. - P.17-24.

5 Pellicer J., Saslis-Lagoudakis C.H., Carrió E., Ernst M., Garnatje T., Grace O.M. A phylogenetic road map to antimalarial Artemisia species // Journal of Ethnopharmacology. - 2018. - Vol. 225. - P.1-9.

6 Ahuja A., Yi Y.S., Kim M.Y., Cho J.Y. Ethnopharmacological properties of Artemisia asiatica: A comprehensive review // Journal of Ethnopharmacology. - 2018. - Vol.220. - P.117-128.

7 Kunaev R.M. Enzymatic cleavage of wormwood flavonoids [Fermentativnoye rasshchepleniye flavonoidov polyni] // Academy of Sciences of the Kazakh SSR: Science [AN KazSSR: Nauka]. - 1973. - №2. - P.89-93. (In Russian)

8 Parameswari P., Devika R. Asian J. Quantitative analysis of bioactive compounds of Artemisia Nilagirica (Clarke) pamp. Leaf extract // Asian Journal of Pharmaceutical and Clinical Research. - 2016. - Vol.9. - P.183-184.

9 Hua F., Jialiang W., Zhenquan W., Liping C. Fatty acid and amino acid compositions of Artemisia sphaerocephala seed and its influence on mouse hyperlipidemia // Chemistry of Natural Compounds. - 2011. - Vol.47. - P.675-678.

10 Muzychkina R.A., Korulkin D.Yu., Abilov Zh.A. Qualitative and quantitative analysis of the main groups of BASes in medicinal raw materials and phytopreparations [Kachestvennyy i kolichestvennyy analiz osnovnykh grupp BAV $v$ lekarstvennom rastitel'nom syr'ye i fitopreparatakh]. - Almaty: Kazakh University, 2004. (In Russian)

11 USSR State Pharmacopeia. - X ed. - M .: Medicine, 1968. - 1080 p. (In Russian)

12 Paperno T.Ya., Pozdnyakov V.P., Smirnova A.A., Elagin L.M. Physical and chemical research methods in organic and biological chemistry [Fiziko-khimicheskiye metody issledovaniya v organicheskoy i biologicheskoy khimii]. - M.: Prosvescheniye, 1977. (In Russian)

13 Esimova O.A., Burasheva G.Sh. Photochemical determination of amino acids in plant materials [Fotokhimicheskoye opredeleniye aminokislot v rastitel'nom syr'ye] // Chemistry of Nature [Khimiya prirody]. - 1991. - №3. - P.453. (In Russian)

14 Panche A.N., Diwan A.D., Chandra S.R., Nutr J. Flavonoids: an overview // Journal of Nutritional Science. - 2016. - Vol.5. ID.e47.

15 Arpita R. A review on the alkaloids an important therapeutic compound from plants // International Journal of plant biotechnology. - 2017. - Vol.3. - P.1-9.

16 Linda P., Case M.S. Canine and Feline Nutrition. - London: Elsevier, 2011. - P.83-84.

17 Thomas S. Functional Dietary Lipids. - London: Elsevier, 2016. - P. 1-20.

\section{References}

1 Pavlov NV (1966) Flora of Kazakhstan [Flora Kazahstana]. Academy of Sciences of the Kazakh SSR, Alma-Ata, Kazakh SSR. (In Russian). ISBN 978-5-458-53242-9

2 Alukina LS, Ryakhovskaya TV (1980) Plant resources [Rastitelnye resursy] 16(2):187-192. (In Russian)

3 Abad MJ, Bedoya LM, Apaza L, Bermejo P (2012) Molecules 17(3):2542-2566. https://doi.org/10.3390/molecules/17032542

4 Altunkaya A, Yildirim B, Ekici K, Terzioglu O (2014) GIDA 39(1):17-24. https://doi.org/10.5505/gida.00710

5 Pellicer J, Saslis-Lagoudakis CH, Carrió E, Ernst M, Garnatje T, Grace OM (2018) Journal of Ethnopharmacology 225:1-9. https:// doi.org/10.1016/j.jep.2018.06.030 
6 Ahuja A, Yi YS, Kim MY, Cho JY (2018) Journal of Ethnopharmacology 220:117-128. https://doi.org/10.1016/j.jep.2018.03.032 7 Kunayeva RM (1973) Academy of Sciences of the KazSSR. Science [Akademiya Nauk KazSSR. Nauka] 2:89-93. (In Russian)

8 Parameswari P, Devika R, Asian J (2016) Asian Journal of Pharmaceutical and Clinical Research 9(2):183.

9 Hua F, Jialiang W, Zhenquan W, Liping C (2011) Chemistry of Natural Compounds 47:675-678.

10 Muzychkina RA, Korulkin DYu, Abilov ZhA (2004) Qualitative and quantitative analysis of the main groups of BASes in medicinal raw materials and phytopreparations [Kachestvennyi $i$ kolichestvennyi analiz osnovnyh grup BAV $v$ lekarstvennom rastitelnom syrie i phitopreparatah]. Kazakh University, Almaty, Kazakhstan. (In Russian). ISBN 9965-12-718-2

11 USSR State Pharmacopeia (1968) [Gosudarstvennaya farmakopeia SSSR]. Moscow, USSR. (In Russian). ISBN 978-5-9901447-1-2

12 Paperno TYa, Pozdnyakov VP, Smirnova AA, Yelagin LM (1977) Physical and chemical research methods in organic and biological chemistry [Fiziko-khimicheskiye metody issledovaniya v organicheskoy i biologicheskoy khimii]. Prosvescheniye, Moscow, Russia. (In Russian)

13 Esimova OA, Burasheva GSh (1991) Chemistry of Nature [Himiya prirody] 3:453. (In Russian)

14 Panche AN, Diwan AD, Chandra SR, Nutr J (2016) Journal of nutritional science 5:47. https://doi.org/10.1017/jns.2016.41

15 Arpita R (2017) International Journal of plant biotechnology. 3:1-9. https://doi.org/10.1155/2017/8528210

16 Linda P, Case MS (2011) Canine and Feline Nutrition. Elsevier, London, UK. P.83-84. ISBN 978-0-32-306619-8

17 Thomas S (2016) Functional Dietary Lipids. Elsevier, London, UK. P.1-20. ISBN 978-1-78-242257-0 